\title{
Correction to: Beyond Formal Access: Organizational Context, Working From Home, and Work-Family Conflict of Men and Women in European Workplaces
}

\section{Tanja van der Lippe ${ }^{1} \cdot$ Zoltán Lippényi $^{1}$}

Published online: 18 May 2019

(c) Springer Nature B.V. 2019

\section{Correction to: Social Indicators Research https://doi.org/10.1007/s11205-018-1993-1}

In the original publication of this article, the acknowledgement section has been missed to publish. Now the acknowledgement has been provided in this correction.

Acknowledgements This paper was supported by the European Research Council under the European Union's Seventh Framework Programme (FP/2007-2013), [ERC Grant Agreement No. 340045].

Publisher's Note Springer Nature remains neutral with regard to jurisdictional claims in published maps and institutional affiliations.

The original article can be found online at https://doi.org/10.1007/s11205-018-1993-1.

Tanja van der Lippe

t.vanderlippe@uu.nl

1 Utrecht University, Utrecht, The Netherlands 